\title{
Sari Salin
}

\section{Seitsemän munaa.}

\section{Pikareski ja parannus Aleksis Kiven romaanissa}

Lukkari. Tietäkäät, he ovat kantaneet kääntymyksen ja parannuksen ihanimpia hedelmiä ja nyt he palauvat rakkaasen syntymäkotoonsa riemun ja kunnian poikina, [- -]. (Seitsemän veljestä, s. 644.)

Juhani. Mutta enhän ole vaan no'essa kasvoiltani?

Eero. Et suinkaan, vaan oletpa puhdas ja lämmin kuin vasta munittu muna. (Seitsemän veljestä, s. 470.)

Kysymystä Aleksis Kiven Seitsemän veljeksen (1870) lajista ei ole esitetty liian usein. Kirjallisuuden lajien pohtiminen on kuulunut kirjallisuudentutkimuksemme paradigmaan vasta vähän aikaa. Se mitä tällä saralla on aikaan saatu, on tapahtunut Mihail Bahtinin tai Alastair Fowlerin vanavedessä. Bahtinin teokset tulivat tunnetuiksi Suomessa 1980-luvulla, ja Fowlerin Kinds of Literature ilmestyi vasta tuolla samaisella vuosikymmenellä (1982). Niin oivaltavasti kuin V. Tarkiainen (1915/1951), V.A. Koskenniemi (1934), Unto Kupiainen (1939) ja Aarne Kinnunen (1973/1987) ovatkin Kiven romaanista kirjoittaneet, heillä ei ole ollut lajin käsitettä työvälineenään. Tästä huolimatta nämä tutkijat käsittelevät, tai ainakin kiertelevät sellaisten kysymysten äärellä, jotka on mahdollista nähdä lajikysymyksinä.

Ainoa tutkimus, joka on nostanut Seitsemän veljeksen lajin tutkimuskysymyksensä keskiöön, on Pirjo Lyytikäisen Vimman villityt pojat (2004). Lyytikäinen liittää Kiven romaanin karnevalisoituneen kirjallisuuden joukon jatkeeksi, ja osuu siinä oikeaan. Lyytikäinen ei ole kuitenkaan tyytynyt siihen, vaan on lisäksi luonut Bahtinin tutuksi tekemälle jatkumolle uuden alalajin, transgressioromaanin. Vaikka uusien lajien keksiminen on kiinnostavaa, tässä tapauksessa uudesta lajista on tullut Kiven romaanille pakkopaita, joka tuntuu välttämättä vaativan, että koko romaanissa on kysymys vain ja ainoastaan transgressiosta, siis rikkomuksista. Tulkinta ei tee oikeutta romaanin lopulle, jossa veljekset sopeutuvat ja tekevät sovinnon yhteiskunnan kanssa, vaan se kieltää tai ainakin julistaa vajavaiseksi romaanin rakenteen.

Lyytikäinen on oikeassa siinä, että lopussa tapahtuva muutos ja kehitys ei ole Kiven romaanin keskeisin asia. Jo V.A. Koskenniemi havaitsi, että Seitsemän veljeksen mieleen painuvinta sisältöä ovat episodimaisesti ja humoristisesti kerrotut seikkailut, tappelut ja toilaukset, "ilostelevat episoodit". "Tällaisten yksityiskohtien rinnalla painuu itse psykolooginen kehitysajatus, mikäli sitä voi katsoa romaania hallitsevaksi motiiviksi, 
taka-alaan ja meidän mielikuvituksemme iloitsee niistä naivin välittömistä, kaikesta tarkoituksellisuudesta vapautuneella huumorilla kuvatuista episoodeista, jotka saavat ikäänkuin itsenäisen aseman mielikuvituksessamme ja joissa tunnemme jotakin väärentämättömän inhimillistä saaneen ilmaisunsa”, Koskenniemi kirjoitti teoksessaan Aleksis Kivi (1934). Väitän silti, että veljesten kokema muutos on tärkeä osa Kiven romaania. Kun Lyytikäinen kirjoittaa, että "[1] oppuluku on nykylukijan kannalta yllättävä ja sitä voisi pitää vammana mestariteoksen rakenteessa” (Lyytikäinen 2004, 254), hän ei sano suoraan, mutta vihjaa kovin selvästi, että loppuluku on tarpeeton osa romaania, heikkous kokonaisuuden kannalta. Tälle ei kuitenkaan ole mitään perusteita. Parannuksenteko kuuluu kyseessä olevaan lajiin, pikareskiin. Loppulukua myös ennakoidaan romaanin keskeisessä peilaavassa rakenteessa, Juhanin unessa. Väheksyä ei sovi myöskään veljesten omantunnon ääntä, joka saa Simeonin näkemään unta Lusifeeruksesta 10. luvussa ja Juhanin hautomaan jopa itsemurha-aikeita 11. luvussa. Veljekset tuntevat katumusta ja kauhua omasta tilanteestaan koko romaanin ajan, ja loppua kohden nämä tunteet voimistuvat.

Seitsemän veljestä on romaani seitsemän pojan kasvusta miehiksi ja siitä, miten he tekevät parannuksen. Se ei kuitenkaan ole opettavainen kehitysromaani (jos mikään hyvä romaani on), vaan humoristinen, "ilosteleva" (kuten Kivi sanoisi) kuvaus seitsemän henkilönsä toilauksista ja seikkailuista sekä lopulta yhteiskuntaan sopeutumisesta. Suhteessa aikansa sivistyneistön käsitykseen kansasta sen sisältöä voi nimittää transgressiiviseksi vain, mikäli annamme painoarvoa Ahlqvistin arvostelutoiminnalle. Kuinka paljon kansankuvaus todella loukkasi muita, terveempiä yksilöitä, on vaikea sanoa, mutta luulisin, että Kiven pahoinpitelyssä oli kysymys professori Ahlqvistin henkilökohtaisista ongelmista ja siitä onnettomasta tosiasiasta, että hänellä oli liikaa valtaa. Jossain mielessä transgressioiden yletön korostaminen on Ahlqvistin arvostelutoiminnan ymmärtämistä, vaikka sitä ei voi ymmärtää. Pikemmin kuin transgressioista on kysymys vakava-naurullisesta lajista, jota Ahlqvistilla ja monella muullakin on ollut vaikeuksia ymmärtää. ${ }^{1}$

Vaikka Aarne Kinnunen ei pohdi Kiven romaanin lajia, hänen huomionsa tutkijoiden (tai muiden huomattavien lukijoiden) suhtautumisesta Kiven huumoriin kuvaa mielestäni juuri vaikeutta suhtautua vakava-naurulliseen lajiin:

Monet ovat pahoittaneet mielensä Kiven romaanin ilostelevuudesta. Toiset taas harmitelleet, ettei se ole läpikotaisin ilosteleva. (Kinnunen 2002, 21.)

Kinnunen asettaa omaan arvoonsa myös Kiven romaanin rakenteen mestaroinnin, josta vaikuttaa muodostuneen suomalaiskansallinen perinne. On kuitenkin epäselvää, ketkä kaikki (Ahlqvistin jälkeen) ovat olleet tosissaan sitä mieltä, että Seitsemän veljestä olisi rakenteeltaan epäonnistunut. Alex Matson väitti Romaanitaiteessaan, että "monet arvostelijat" (jotka jäävät nimeämättä) ovat pitäneet 14. lukua "taiteellisena hairahduksena" 
(1947/1969, 65). Vaikka Matson ei itse tälle kannalle asetukaan, keskustelusta käy ilmi, että ilmeisesti kysymys on ollut nimenomaan huumorin suhteellisesta vähenemisestä viimeisessä luvussa. Matti Kuusi (1984) taas on ihmetellyt 12. lukua ja selittänyt sen poikkeavan muusta romaanista teoksen syntyhistoriasta johtuvista syistä. "Merkillisintä on luvun melkein täydellinen huumorittomuus", Kuusi sanoo (1984, 26) Hän arvelee, että jos Kivi tarjoaisi teostaan kustannettavaksi vuonna 1984, kustannusvirkailija "neuvoisi XII luvun pyyhkimistä" (mt. 28; ks. myös Kupiainen 1939, 185). Kuusikin tosin hyväksyy 12. luvun loppujen lopuksi sillä perusteella, että sen pois jättämisen myötä "taideteoksen yhtenäisyys voittaisi, inhimillinen dokumentti menettäisi” (Kuusi 1984, 28). Kaikesta tästä voidaan päätellä, että Kiven lukijoilla on usein ollut vaikeuksia suhtautua tekstiin, joka on yhtä aikaa sekä vakavaa että ilostelevaa.

Seitsemän veljeksen on perinteisesti nähty sijoittuvan realismin ja romantiikan välimaastoon (esim. Tarkiainen 1915/1951, 7). Kiven huumori näyttää kuitenkin saavan esikuvansa muualta, nimittäin renessanssin mestareilta, Shakespearelta ja Cervantesilta, joita Kivi tunsi hyvin. Suomalaiset tutkijat ovat aina ymmärtäneet renessanssihuumorin merkityksen Kiven romaanissa. Kiven humoristista puolta on mielestäni tutkittu ansiokkaasti ilman lajiteoriaakin. Kinnunen (1973/1987) on analysoinut Kiven ironiaa ja huumoria, ja Tarkiaisen (1915/1951, 439-453) analyysi Kiven kielestä ja tyylistä ja niiden merkityksestä romaanin huumorin kannalta on edelleen lukemisen arvoinen. Lajin kannalta on erityisen kiinnostavaa, että Seitsemän veljeksen esikuvana on usein pidetty Don Quijotea.

Tässä artikkelissa osoitan, että Seitsemää veljestä on hedelmällisintä tarkastella pikareskin lajiin kuuluvana romaanina. Tällöin meidän ei tarvitse amputoida tätä ensimmäistä - ja monista edelleenkin ylittämätöntä - suomenkielistä romaania, vaan voimme hyväksyen lukea sen loppuun saakka; loppuun, jossa veljesten seikkailullinen elämä muuttuu parannuksenteoksi ja sopeutumiseksi. Kuten espanjalaisen hidalgon koomiset harharetket päättyvät järkiintymiseen, myös veljekset muuttuvat lopussa suhteellisen kunnollisiksi kansalaisiksi. Vaikka Seitsemän veljestä ei ole "tyypillisin" veijariromaani, eikä selkein lajiesimerkki, pikareski on ilman muuta laji, joka parhaiten kuvaa Kiven romaania.

Lajikäsitteen käyttökelpoisuus tutkimusvälineenä riippuu siitä, miten se pystyy avaamaan ja tulkitsemaan yksilöllisiä romaaneja. Mihail Bahtin on korostanut jokaisen teoksen olevan ennen kaikkea lajinsa edustaja, mutta toisaalta painottanut myös sitä, miten jokainen teos muokkaa edustamaansa lajia (esim. Bahtin1991, 157). Alastair Fowler $(1982,41)$ lainasi Wittgensteinin perheyhtäläisyys-käsitteen kuvaamaan sitä, miten yksilöllinen teos liittyy lajiin. Jokainen romaani on yksilöllinen teos, mutta yksikään romaani ei ole saari, vaan se liittyy lukemattomin perheyhtäläisyyksin muihin romaaneihin. Silloin kun yksilöllinen romaani sisältää tarpeeksi monta jonkin lajin 
piirrettä, se voidaan katsoa kuuluvaksi tuohon lajiin. Yksikään romaani ei silti täytä kaikkia lajikriteerejä, ja jokainen romaani on tavallaan oman lajinsa tai alalajinsa muunnelma. Seitsemässä veljeksessä on kehitysromaanin piirteitä siinä mielessä, että veljekset muuttuvat ja kehittyvät kertomuksen aikana. Pikareskiin kuuluvat erilaiset seikkailut, toilaukset ja selkäsaunat, ja lopussa yleensä tapahtuu kääntymys tai parannus, tosin usein ironisesti värittyneenä. Koska juoni on pikareskin lajin kannalta olennainen, käsittelen seuraavaksi keskeistä juonta peilaavaa mise en abymea, Juhanin munaunta. Sen jälkeen pyrin lyhyesti esittelemään pikareskin lajia.

\section{Muna vertauskuvana}

Kananmuna on yksi Seitsemän veljeksen tärkeimmistä johtomotiiveista, joka toimii milloin motiivina, milloin kuvana ja milloin taas symbolina. Sen kohosteisuus ei johdu ainoastaan toistumisesta, vaan myös siitä, miten muna saa toimia vertauskuvana veljesten elämästä. Alun upotettu kertomus munavarkaudesta on esimerkki nuorten veljesten kurittomuudesta. Tämän kertomuksen kertoja kertoo kokonaan itse, ilman että veljekset saavat suunvuoroa, sillä kertoja muistelee alussa veljesten nuoruutta ikään kuin takautumana. Munavarkaus on veljesten nuoruuden rikkomuksista ainoana kuvattu tarkoin, mutta lukijalle tulee selväksi, ettei se suinkaan ollut heidän ainoa rikkomuksensa. Makoisilta maistuvat nuotion tuhkassa paistetut munat havainnollistavat veljesten rosvoelämän nautinnollista puolta.

Vertauskuvaksi munat pääsevät toisessa luvussa Juhanin kertoessa unestaan, jota Lyytikäinen (2004, 27-29) on analysoinut romaanin keskeisenä peilirakenteena eli mise en abymena. Munauni on keskeinen peilirakenne nimenomaan sen vuoksi, että se heijastaa romaanin juonen kaarta kokonaisuudessaan. Juhani kertoo toisessa luvussa nähneensä unessa kananpesän, jossa oli seitsemän munaa. Munien lukumäärä paljastaa heti paralleelin romaanin seitsemään päähenkilöön, vaikka Juhani ei näytä itse huomaavan sitä. Sen sijaan Simeoni ymmärtää unen vertauskuvallisuuden heti ja tulkitsee unta samanaikaisesti Juhanin kertomuksen kanssa:

Juhani. Uneksuinpa, että oli tuolla uunin päällä kananpesä ja siinä seitsemän munaa.

Simeoni. Jukolan seitsemän poikaa!

Juhani. Mutta yksi munista oli hassun pikkuinen.

Simeoni. Eero!

Juhani. Kukko kuoli!

Simeoni. Isämme!

Juhani. Kana kuoli!

Simeoni. Äitimme! (Seitsemän veljestä, s. 468-469.)

Tähän saakka uni peilaa veljesten elämää ennen tarinan aikaa, siis tapahtumia, jotka kertoja romaanin alussa kertoo takautumina. Äiti ja isä ovat kuolleet, ja pojat ovat siis 
orpoja. Orpous on merkittävää lajin kannalta, sillä pikareskin sankari on usein orpo tai ainakin osaton ja ulkopuolinen, ja sellaisena pakotettu jättämään kotinsa ja kokemaan seikkailuja maailmalla. ${ }^{2}$ Tämän jälkeen alkaa varsinainen enneuni, joka kuvaa seikkailuja yhteiskunnan ulkopuolella ja niiden seurauksia, munien särkymistä:

Juhani. Sittenpä kohta kaiken maailman hiiret, rotat ja kärpät pesän kimppuun. - Mitäpä nämät elävät tarkoittaa?

Simeoni. Syntisiä himojamme ja maailman hekumaa.

Juhani. Kaiketi niin. - Tulivatpa kärpät, rotat ja hiiret ja kierittelivät ja vierittelivät, kolistelivat ja kalistelivat munia, jotka pian särkyivät, ja siitä pikkuisesta munasta lemahti kovin karvas haisu.

Simeoni. Huomaa tämä, Eero. (Seitsemän veljestä, s. 469.)

Simeonin tulkinta "syntisistä himoista ja maailman hekumasta" on tyypillistä Simeonia, joka on kiihkeä uskovainen, mutta onko tulkinta oikea? Onko Juhanin vastauksessa "kaiketi niin" varautuneisuutta? Nykylukijan voi olla vaikea havaita, mitä syntejä ja "hekumoita" veljeksillä on tunnollaan. Lukutaidottomuus on romaanin tässä vaiheessa veljesten pahin synti; kuten Aapo ensimmäisen luvun lopussa toteaa, lukutaito on "kristillisen kansalaisen välttämätön velvollisuus" (Seitsemän veljestä, s. 466). Lukutaidottomuus sulkee yksilön paitsi kristinuskon, myös kansalaisoikeuksien ulkopuolelle. Yhteiskunnan ja kansalaisuuden ulkopuolella mesoaminen saa siis munat särkymään. Pienen, haisevan munan Simeoni tulkitsee vaivattomasti tarkoittavan Eeroa, eikä kukaan vastusta tätäkään tulkintaa.

Juhani. Munat rikottiin ja hirmuinen ääni, kuin monen kosken pauhu, nyt huusi mun korvaani uunin päältä: "kaikki on rikottu, ja se rikkomus oli suuri!" Niin huudettiin, mutta rupesimmepa viimein kuitenkin kokoilemaan ja keittelemään tuota seka-melskaa, ja saimme siitä lopulta sitä niin kutsuttua munakokkoa eli munakokkelia; ja me söimme sitä vallan mieluisasti ja annoimme myöskin naapureillemme.(Seitsemän veljestä, s. 469.)

Tämän jälkeen unenselittäjä vaikenee ja jättää tilaa Eeron leukailulle. Simeoni vaikenee, koska Juhanin unen loppu on arvoitus, johon lukija, kuten Simeoni itsekin, saa vastauksen vasta romaanin lopussa. Näin romaani ennakoi omaa juontaan aina loppuun saakka. Mikä on se ääni, joka huutaa Juhanin korvaan? Omantunnon äänikö, vai yhteiskunnan tuomion ääni? Kenties kumpaakin. Joka tapauksessa rikkomuksista seuraa ankaria moitteita. Sen jälkeen veljekset ottavat lusikan kauniiseen käteen ja alkavat keitellä munakokkelia noista munista, eli itsestään. Loppujen lopuksi kokkelista tulee hyvää ja se kelpaa naapureillekin, toisin sanoen uni ennustaa, että lopussa tapahtuu parannus ja sovinto yhteiskunnan ja yhteisön kanssa.

Unessa rikkoutuvat, hiirien ja rottien tärvelemät ja osittain pahanhajuiset munat muuttuvat lopulta oivaksi eineeksi. Unen tulkinta käy kiusalliseksi Lyytikäiselle, joka haluaa kieltää munakokkelivaiheen merkityksen. 
Päätöksen koominen ja "matala" äänilaji jättää kuitenkin auki lopun tulkinnan. Toisin sanoen mise en abyme ei vielä ratkaise rikkomuksen ja sovituksen, transgression ja "kehityksen" saamaa painoarvoa romaanissa, mutta kertoo lukijalle, että näistä ja näiden suhteesta on kysymys. Kommenttina ja ennakointina se on leikillinen, ironinenkin; omiaan vaimentamaan kiusausta didaktiseen tulkintaan. (Lyytikäinen 2004, 29.)

Tietenkään "mise en abyme ei vielä ratkaise" mitään romaanin tässä vaiheessa, mutta romaanin kokonaisuuden valossa lukija kyllä näkee, että uni ennustaa sovitusta ja parannusta. Lyytikäinen kieltää sovituksen ja kehityksen vetoamalla enneunen koomisuuteen, vaikka itse ennen tulkintaansa on sanonut, että "kohtaus on koominen mutta itse ennusmerkki silti merkityksellinen" (mt. 27). On totta, että koomisuus ja ironisuus pehmentää opettavaisuutta, ehkä jopa tekee sen mahdottomaksi. Transgressiivisuus vastaan didaktisuus onkin väärä lähtökohta Kiven romaanin tulkinnassa. Kysymys on vakava-naurullisesta lajista, joka tarkoittaa sitä, että vakavuus ja koomisuus sekoittuvat kaikkialla. Pikareskin päähenkilölle on tyypillistä parannuksen ja kääntymyksen haikailu. Silti itse parannuksenteko usein ironisoituu ja osoittautuu mahdottomaksi. Näin ei käy kuitenkaan Don Quijotessa, Kiven tärkeimmässä romaaniesikuvassa. Hullu ritari saa lopussa järkensä takaisin ja katuu syvästi hulluuden vallassa kokemiaan seikkailuja. Silti Don Quijotea on mahdotonta lukea didaktisena kehitysromaanina, niin tärkeitä ja filosofisia nuo loputtomat, episodimaisesti kuvatut seikkailut siinä ovat.

Munan symboliikka on jäänyt tutkijoilta aiemmin huomaamatta. Miksi Juhanin unessa esiintyy juuri seitsemän munaa, eikä vaikkapa seitsemän naurista? Olivathan veljet nuorempina käyneet naurisvarkaissakin. Muna symboloi veljesten keskenkasvuisuutta ja kasvun ja muutoksen potentiaalia. Munan symboliset merkitykset ovat moninaisia, mutta ne liittyvät yleensä uuden elämän mahdollisuuteen ja hedelmällisyyteen. Orfilaisissa luomismyyteissä maailma syntyi alkumunasta, kuten Kalevalan alun maailmansyntyrunossakin (Biedermann 1993, 228). Kristillisessä ja etenkin ortodoksiperinteessä (pääsiäis)muna symboloi Kristuksen kätkettyä elämää ja ylösnousemusta: legendan mukaan Maria Magdaleena antoi keisari Tiberiukselle punaiseksi värjätyn munan merkiksi ylösnousemususkosta (Kasala 1991, 28). Uuden elämän merkitys Juhanin unessa voisi tietenkin olla selvempi ja vakavampi, mikäli munista tosiaankin kuoriutuisi untuvikkoja. Sen sijaan ne rikkoutuvat maailman melskeissä, yhdestä purkautuu "karvas haisu", ja lopulta niistä tehdään munakokkelia. Kuten Lyytikäinen on todennut, tällaisena uni on väritykseltään koominen. Munakokkeli, olkoonkin koomista, on kuitenkin ruokaa ja sellaisena hyödyttää yhteisöä. Vakava-naurulliseen kirjallisuuteen suhtautuminen ei aina ole helppoa, sillä lukijan on otettava samanaikaisesti vastaan sekä koominen että vakava merkitys.

Munan ja lukutaidon yhteys romaanissa on vahva, vaikka sekin on yleensä koomisesti esitetty. Munauni muistuu Juhanin mieleen nimenomaan aapiskukon 
kuvasta aapisen kannessa. Unen kertomisen jälkeen Eero jatkaa Juhanin mielleyhtymää esittämällä oman enneunen parodiansa: hän on muka nähnyt unta siitä, miten aapiskukko on muninut Juhanille makeisia palkinnoksi hänen ahkeruudestaan. Tämä on tietysti Eeron tyypillistä leukailua, sillä Juhani on kaikkea muuta kuin kunnostautunut lukemisen harjoittelussa. Koomista on jo ylipäätään se, että kukko munii. Väistämätön assosiaatio lisää koomisuutta, nimittäin sanonta "kun koville ottaa, niin kukkokin munii” - ja kovillehan se lukemaan opettelu ottaa, niin Juhanilla kuin muillakin veljillä Eeroa lukuun ottamatta. Koomisuus ei kuitenkaan tee tyhjäksi näitä mielleyhtymiä.

Lukutaito on oleellinen seikka yhteiskuntaan sopeutumisessa. "Munakokkelia" syntyy vasta kun lukutaito on saavutettu, ja sen tekemiseksi täytyy rikkoa munia. Moderni tietoyhteiskunta on Kiven romaanissa syntymäisillään, ja veljekset ovat esimerkkejä tästä muutoksesta. Uusi yhteiskunta on myös entistä demokraattisempi. Lukeminen on tärkeä motiivi myös Don Quijotessa, vaikka jo historiallisista syistä sen suhde lukutaitoon ja kirjallisuuteen on hyvin erilainen. Köyhtynyt aatelismies Don Quijote on lukenut liikaakin omaksi hyväkseen, tai ainakin väränlaista kirjallisuutta, tai ainakin väärällä tavalla. Sancho Panza sen sijaan ei osaa lukea, eikä häneltä sellaista odotetakaan. Cervantesin yhteiskunnassa lukutaito kuului vain ylemmille sosiaaliluokille, ja hänen romaanissaan lukutaito ja sen ylellinen väärinkäyttö kuuluu eliitille. Don Quijoten kehityksessä on kysymys paitsi hulluudesta paranemisesta myös roskakirjallisuuden vaikutteiden hylkäämisestä. Kiven kuvaamassa yhteiskunnassa sen sijaan kaikkien on opittava jonkinlainen lukutaito saavuttaakseen täydet kansalaisoikeudet. Suullisesti välitetyt tarinat hallitsevat silti vielä suomalaista kulttuuria, ja niihin veljekset turvautuvat ja niitä he väärinkäyttävät, esimerkiksi saadessaan vaikutteita Taula-Matin metsästysretkistä.

Hedelmällisyyden vertauskuvana muna tietenkin liittyy seksuaalisuuteen, mutta sillä on myös erityinen suhteensa miehen fysiologiaan. Miehen kivekset on usein yhdistetty muotonsa takia muniin (Biedermann 1993, 228). Suomen kielessä munalla on hyvinkin suoria seksuaalisia merkityksiä. Puhekielessä "munilla" tarkoitetaan miehen kiveksiä, ja yksikössä "muna" viittaa myös penikseen. Käyttö näkyy suomen murteissa ja sananlaskuissa (ks. Jussila \& Länsimäki 1994, 333-334), joten se on vanhaa perua. Onko Kiven romaanin munilla seksuaalinen merkitys? Juhanin munauni, kuten myös Eeron pääsiäiskukkoparodia sekä tämän artikkelin toisessa motossa lainattu Eeron sutkaus sijoittuvat romaanin toisessa luvussa kohtaan, jossa vallitsee tietty eroottinen viritys: ovathan veljekset lähdössä joukolla "naima-asioille”, mikä tosin tarkoittaa tässä vain Männistön Venlan kosimista. Kiven tekstin munavertauksilla ja -puheilla ei kuitenkaan ole varsinaista seksuaalista merkitystä. Ensinnäkään dialogissa ei käytetä miehen sukupuolielimistä kyseistä ilmausta, eikä sukupuolielimiin viitata millään muullakaan sanalla. Kiven teksti on huomattavasti siveämpää kuin kansan puhekieli on vanhastaan 
ollut. Toisin olisi varmaan ollut, jos Kivellä olisi ollut kirjahyllyssään Rabelais'ta - puute, jota myös Tarkiainen ja Cygnaeus ovat harmitelleet (Tarkiainen 1915/1951, 437438). Toiseksi on tärkeää huomata munan yleisen symboliikan lisäksi sen Kiven tekstin kontekstissa saama erityinen merkitys. Ainakin Juhanin unessa muna merkitsee pikemmin viattomuutta, joka meidän kulttuurissamme on seksuaalisuuden vastakohta. Muna merkitsee siis paitsi kehityksen potentiaalia, myös viattomuutta ja turmeltumattomuutta, lukuun ottamatta Eero-munaa, joka on valmiiksi pilalla. Samaa viattomuuden ja puhtauden tematiikkaa jatkaa irvailevasti Eeron sutkaus kosimaan lähtevälle Juhanille: ”oletpa puhdas ja lämmin kuin vasta munittu muna”. Tämä on tietysti Eeron kuitti Juhanille siitä, että tämän unessa pikkuisesta Eero-munasta lähti paha haju. Eikä kosimaan lähtevälle vanhimmalle pojalle ole välttämättä kunniaksi, että häntä verrataan vasta munittuun munaan, joka on untuvikkoakin turmeltumattomampi. Seksuaalisuuden korostamisen sijaan munaan vertaaminen mitätöi Juhanin seksuaalisesti.

\section{Pikareskilajin jäljillä}

Mihail Bahtin on määritellyt pikareskin vakava-naurullisuuden kirjallisuuden eli karnevalisoidun genren jatkajaksi (Bahtin 1979, 271-290). Pikareskin (la novela picaresca) katsotaan syntyneen Espanjassa 1500-luvun loppupuolella, vaikka sen esiisiä on mahdollista osoittaa esiintyneen antiikin Roomassa ja muinaisessa Egyptissä. ${ }^{3}$ Suomenkielinen nimitys "veijariromaani” paljastaa espanjankielistä nimeä paremmin, että laji on yhteydessä ikivanhaan, universaaliin triksteri- ja narriperinteeseen. ${ }^{4}$ Pikareski on yksi maailman tunnetuimpia lajeja, ja levinneimpiä; onpa puhuttu jopa "pikareskin viruksesta" (Dunn 1993, 16) ja tarkoitettu sitä joustavuutta, jolla laji on levinnyt kautta aikojen ja maanosasta toiseen.

Useimmat pikareskitutkijat (esim. Guillén 1971; Wicks 1989 myötäilee edellistä) ovat yhtä mieltä siitä, että pikareskiin tarvitaan pikaro eli veijari, joka on orpo, tai ainakin köyhä ja turvaton, siinä määrin, että joutuu lähtemään maailmalle etsimään parempaa elämää ja itseään. Pikaron ja hänen yhteisönsä välillä on yleensä konflikti, vaikka se voikin olla luonteeltaan monenlainen. Usein varsinainen veijarius varsinkin rikollisessa mielessä kehittyy vasta maailmalla, kun kokemukset turmelevat sankarin viattomuuden. Seikkailut ja kovat kohtalot, menestykset ja selkäsaunat seuraavat sitten sarjana toisiaan. Rakenteen episodimaisuutta eli sarjamaisuutta pidetään varsin yleisesti tärkeänä pikareskin kriteerinä (Guillén 1971, 84-85). Espanjalaiset pikareskitutkijat ovat niin ikään usein korostaneet minämuotoista kerrontaa pikareskin tunnusmerkkinä (Guillén 1971, 81).

Pikareskitutkimus ei ole kuitenkaan yksimielistä, ja yleinen käsitys lajista poikkeaa huomattavasti pikareskitutkijoiden näkemyksistä. Perinteinen espanjalainen pikareskitutkimus, niin sanottu historiallinen pikareskitutkimus, on hyväksynyt pikareskeiksi vain muutaman espanjalaisen ns. kultakaudella eli Espanjan suuruuden 
aikana (1500-luvun lopulta 1600-luvun alkupuoliskolle) ilmestyneen romaanin (Lazarillo de Tormes, El Buscón, Guzmán de Alfarache). Hispanistit siis ovat korostaneet pikareskin historiallista kontekstia, ja pikareski kuvaa heidän mukaansa nimenomaan tiettyä ajanjaksoa Espanjan historiassa ja sen sosiaalisia olosuhteita. Tiukan historiallisen lajimääritelmän ongelma on se, että se ei hyväksy kuin muutaman prototyyppisen pikareskiromaanin olemassaolon. Historiallisen määritelmän vastakohtana voi pitää nykyisin yleistä tapaa nimittää mitä hyvänsä seikkailuromaania pikareskiksi. Jälkimmäisen ongelma on siinä, että lajin kriteerit muuttuvat niin salliviksi, että koko laji lakkaa olemasta käsitteenä mielekäs. Claudio Guillénin näkemys torjuu sekä suljetun historiallisen näkemyksen että liian sallivuuden. Guillén näkee lajin universaalisuuden ja hyväksyy sen, että myös muut kuin kultakauden Espanjassa kirjoitetut romaanit saattavat olla pikareskeja. Guillén on luetellut pikareskilajin kriteerejä, mutta esittänyt myös pikareskin laajemman määritelmän (Guillén 1971, 93-94), joka ennakoi Alastair Fowlerin näkemystä perheyhtäläisyyksistä. Toisin sanoen teoksen ei tarvitse täyttää kaikkia tai edes useimpia lajin kriteerejä ollakseen silti lajin jäsen.

Perinteinen espanjalainen tutkimus on tyypillisesti korostanut, että pikareskin kertoja on pikaro itse, toisin sanoen pikareskiromaanissa on aina oltava homodiegeettinen minäkertoja. Guillén kuitenkin myöntää, että on myös pikareskiromaaneja, joissa kertoja on heterodiegeettinen, ja jopa erinomaisia sellaisia (esimerkkinä hiukan yllättävästi Kafkan Amerikka; Guillén 1971, 97). Tästä huolimatta Guillén ei pidä Don Quijotea pikareskiromaanina, vaan näkee sen kuuluvan "vastagenreen", joka reagoi samaan aikaan suosittuun pikareskin lajiin ja ikään kuin vastustaa sitä. ${ }^{5}$ Guillénin tärkein perustelu koskee kerronnan muotoa: Don Quijoten kertoja on heterodiegeettinen. ${ }^{6}$ Kuitenkin Guillén itse samassa tekstissä myöntää, ettei edes kerronnan minämuotoisuus ole välttämätön lajikriteeri. (Ks. Guillén 1971, 93-99.)

Itse olen taipuvainen pitämään Cervantesin romaania pikareskina. ${ }^{7}$ Don Quijoten yhtäläisyydet pikareskilajin kanssa ovat niin selvät, että on syytä uskoa Guillénin kehittäneen "vastagenren" ajatuksen vain voidakseen nojautua perinteiseen espanjalaiseen pikareskitutkimukseen, vaikka toisaalta onkin täysin eri linjoilla. Vaikka Guillén on hahmotellut mielessään kaavion, joka esittää lajin "kovaa ydintä" ja sen ympärillä kiertäviä löyhemmän lajiin kuulumisen renkaita (kuvaksi tämän kaavion on piirtänyt Wicks 1989, 40), kirjallinen laji muistuttaa pölyvillakoiraa siinä, että sen kovaa ydintä (välttämättömiä kriteerejä) on usein mahdoton osoittaa. Tämä ei ole lajiteorian heikkoutta vaan kirjallisen lajin luonne. Perinteisen pikareskitutkimuksen rajoittuneisuus ei tunnu muutenkaan vastaavan tutkimuksen tarvetta nykytilanteessa. Yksi syy siihen, ettei Don Quijotea ole pidetty pikareskina, saattaa olla pikareskin huono maine. Pikareskeja ei aina ole pidetty oikeina romaaneina, eikä lajin nykyedustajia nykyisinkään juuri arvosteta. 
Don Quijote eroaa kuuluisimmista espanjalaisista pikareskeista siten, että päähenkilö jatkaa narriperinteen hulluutta kuvaavaa haaraa eikä niinkään kuulu varsinaisten veijarien alaosastoon, vaikka narreilla, hulluilla ja veijareilla onkin vankka yhteinen historia (ks. Salin 2008). Don Quijote ei ole rikollinen eikä henkipatto, vaan narrihahmo. Yhteistä pikareskin kanssa on eniten rakenteessa ja juonessa. "Tien päällä" oleminen, joka paljastaa asioita yhteiskunnan eri kerroksista ja sosiaaliluokista, seikkailut, pieksennät ja muut kommellukset liittävät Don Quijoten juonen aikansa pikareskeihin. Rakenteen episodimaisuus Cervantesin romaanissa mahdollistaa tarinan jatkamisen potentiaalisesti loputtomiin. Don Quijote on malliesimerkki romaanista, joka rakentuu televisiosarjan lailla (jos äärimmäisen anakroninen vertaus sallitaan): jokaisessa luvussa, kuten tv-sarjan jaksossa, koetaan uusi seikkailu. Seitsemän veljeksen rakenteen episodimaisuus on myös pantu merkille usein, ja sitä on pidetty draamallisena (Koskenniemi 1934, 228), eeppisenä (Kinnunen 1973/1987, 12) ja toisaalta Kupiaisen tavoin koomisena piirteenä. Rakenteen episodimaisuus mahdollistaa myös monilajisuuden, toisin sanoen sisäkertomusten, laulujen ja runojen sirottelun kerronnan lomaan. Tämä piirre on pantu merkille myös Seitsemässä veljeksessä, ja jotkut tutkijat ovat pitäneet sitä vaikutteena Cervantesilta. "Kuten Cervantes, niin Kivikin punoo romaaniinsa välikertomuksia, satuja, tarinoita ja lauluja", kirjoittaa Tarkiainen $(1915 / 1951,390){ }^{8}$

Miten sitten istuu pikareskitulkintaan se, että Seitsemässä veljeksessä ei ole yhtä veijaria, vaan peräti seitsemän? Useimmissa pikareskeissa on yksi keskushenkilö. Cervantesin romaanissa sen sijaan päähenkilöitä on kaksi lähes tasaveroista päähenkilöä, Quijote ja Sancho Panza, sillä he ovat erottamattomia. Karnevalistinen parivaljakko jatkaa narriperinteen Shakespearen kuningas ja narri -asetelmaa, tai Horatiuksen herra ja orja -asetelmaa. Cervantesiinkin verrattuna Kivi on kuitenkin ollut omaperäinen. Kollektiivinen päähenkilö on yleensäkin romaanissa harvinainen. Kivi-tutkimus ei ole juurikaan pohtinut, miksi Kivi otti romaaniinsa niin monta tasaveroista (tai lähes tasaveroista) päähenkilöä. Sen sijaan on pitkällisesti pohdittu kylläkin sitä, miksi heitä on juuri seitsemän (Kinnunen 1987, 25-37). Yksi selitys voisi olla draaman voimakas vaikutus: näytelmässä yksi selkeä päähenkilö ei ole lainkaan yhtä tyypillinen piirre kuin romaanissa. Osuvampi selitys lienee kuitenkin, että Kivi halusi kuvata veljesten muodostamaa yhteisöä, ei niinkään yksilöä, vaikka kaikki veljekset ovatkin yksilöitä. Tarkiaisen mukaan Kiven romaanissa on olennaista juuri yhteisöllisyyden kuvaaminen. Veljekset on ennen kaikkea esitetty joukkona: "Heissä vallitsee entisajan yhteishenki, tuo perhe- ja kylähenki, jota Kivi ylistää eräässä kirjeessään suomalaisen kansan tuntomerkiksi” (Tarkiainen 1915/1951, 405). Unto Kupiainen taas on osoittanut, että Seitsemän veljeksen huumori syntyy ennen kaikkea tämän yhteisöllisen kuvauksen ja kollektiivisen päähenkilön ansiosta (Kupiainen 1939, 138). Herra ja narri -asetelma sisältyy tähän seitsikkoon siten, että pikkuinen Eero toimii älyllisenä oppositiona ja 
narrina satirisoiden kaikkia veljiänsä (Kinnunen 1973/1987, 60; Kupiainen 1939, 145-147). Pikareskissa seitsemän päähenkilöä on siis varsin omaperäistä. Toisaalta veljekset muistuttavat veijareita enemmän kuin Quijote ja Sancho. Veljesten repäisevä irrallisuus ja ajoittainen lainsuojattomuus tekee heistä jopa klassisia veijareita.

Lajille on ominaista, että siihen liittyäkseen teoksen tekijän ei tarvitse tuntea kaikkia lajiin kuuluvia yksilöitä eikä välttämättä edes useita. Kiven liittyminen lajiin on huikea esimerkki siitä, miten Bahtinin käsite "lajin muistamisesta" toimii. Kirjailijan ei tarvitse olla asiasta edes tietoinen, vaan teos itse "muistaa" lajinsa. Kysymys ei ole yliluonnollisesta ilmiöstä vaan alitajunnan toiminnasta ja kirjoittamisen yliyksilöllisestä luonteesta. (Bahtin 1991: 157-158.) Kivi tunsi tuskin muita pikareskeja kuin Don Quijoten, mutta se riitti. Cervantesin lukeminen aktivoi prosessin, jonka tulokseksi tuli Seitsemän veljestä. ${ }^{9}$

Mörne ja Tarkiainen ovat itse asiassa tietämättään kuvailleet Kiven romaania pikareskina tarkastellessaan sen rakennetta sekä suhdetta Cervantesin Don Quijoteen. Tarkiaisen mukaan suhde on pantu merkille usein aiemminkin.

Täytyneekin myöntää, että sillä [Don Quijotella] on ollut melkoinen vaikutus "Seitsemään veljekseen" ja ennen kaikkea siksi, että siinä asetetaan $\mathrm{h}$ u $\mathrm{m}$ o r i s t i s e e n valoon samanlaatuisia luonteita ja pyrkimyksiä kuin Kiven teoksessa. Itse juonen peruskaavaus jo osoittaa läheistä sukulaisuutta. Kumpaisessakin romaanissa jättävät sankarit kotinsa ja kontunsa lähteäkseen ajamaan takaa kuviteltua päämäärää, kumpaisessakin he joutuvat hullunkurisiin seikkailuihin, joissa heidän lapsellinen yksinkertaisuutensa paljastuu naurettavaksi, ja kumpaisessakin on lopputuloksena retkikunnan kotiinpaluu ja järjen kirkastuminen romanttisista sumuista. (Tarkiainen 1951, 390.)

Tarkiainen tiivistää tässä kiitettävän selkeästi Kiven ja Cervantesin romaanien lajisuhteen vertaamalla niiden juonia toisiinsa. Kun Tarkiainen puhuu Cervantesin "yleissuuntaa koskevasta vaikutuksesta” Kiven romaaniin (Tarkiainen 1951, 393) hän puhuu selvästi pikareskin lajista, vaikkei hänellä ole lajin käsitettä. Myös Arvid Mörne on korostanut yhteyttä Kiven ja Cervantesin välillä:

Man fattar att "Don Quijote” vart Kivis käraste läsning. Detta verks bullrande och lantliga scener, dess motsättningar mellan äventyrens glittrande spel på ytan och de spörjande tankarnas dunkla värld där under, dess dolda fonder av levnadsvisdom måste ha tjusat författaren av "Seitsemän veljestä". (Mörne 1911, 92.)

Mörne vertailee kirjailijoiden romaaneja toisiinsa tehden kiinnostavia havaintoja, jotka tosin jäävät irrallisiksi, mutta tulee samalla luetelleeksi piirteitä, jotka ovat tyypillisiä pikareskin lajille. Mörne näkee samankaltaisuuksia veljesten ja Don Quijoten kotiinpaluiden välillä (mt. 94), ja havaitsee myös, että sekä Kiven että Cervantesin sankarit seikkailujensa aikana kokevat pahoja selkäsaunoja ja toipuvat niistä kuin ihmeen kaupalla, ilman kuolemantapauksia tai pysyviä vammoja (mt. 97). Mörne näkee yhtä- 
läisyyksiä myös elämänviisaudessa, ja pikareski onkin olennaisesti filosofinen laji, jonka päähenkilö etsii elämänviisautta ja -kokemusta (vrt. Guillén 1971, 82).

"Romanttiset sumut" Cervantesin ja Kiven sankareiden toiminnan taustalla poikkeavat kyllä toisistaan, ja veljesten seikkailut verrattuna Don Quijoten ja Sancho Panzan seikkailuihin ovat toki varsin erilaisia. Veljekset pakenevat Impivaaraan, korpeen, ollakseen vapaita ja oman itsensä herroja, ja välttyäkseen lukuopetukselta. Don Quijote luulee olevansa ritari ja kokevansa ritariromaaneista tuttuja seikkailuja, esimerkiksi tappelevansa jättiläisiä ja noitia vastaan. Vaikka pikareskissa ollaan matkalla, olennaista ei ole se, miten kauas matkustetaan. Tärkeintä ovat yhtä aikaa koomiset ja traagiset törmäykset, jotka opettavat pikarolle jotakin hänestä itsestään. Lopulta elämänviisaus löytyy, mutta vakava-naurulliselle lajille on tyypillistä, että tuo viisauskin esitetään paitsi vakavana myös naurullisena, toisin sanoen inhimillisen puutteellisena ja suhteellisena.

\section{Riemun ja kunnian pojat}

Seitsemän veljeksen lopussa veljekset katuvat hurjaa elämäänsä ja palaavat yhteiskuntaan. He oppivat lukemaan ja perustavat oman kodin ja perheen. Heistä tulee "riemun ja kunnian poikia", kuten lukkari ilmaisee juhlalliseen tyyliinsä. Mutta tuleeko heistä täydellisiä ihmisiä ja kansalaisia? Ei tietenkään, eikä pikareskin laji sitä vaadikaan.

Pikareskin historialliset juuret kietoutuvat tunnustuskirjallisuuteen, mistä johtuu myös se, että pikarot kokevat lopussa usein kääntymyksen tai tekevät parannuksen. Vähintäänkin pikaro asettuu lopussa aloilleen ja aloittaa uuden vakaamman elämänvaiheen, toisin sanoen konflikti yksilön ja yhteisön välillä laukeaa. Pikareskille on toisaalta tyypillistä myös tämän kääntymyksen tai parannuksen ironisoituminen. Esimerkiksi Grimmelshausenin Seikkailukkaassa Simplicissimuksessa päähenkilö jatkuvasti haikailee parannusta ja kuitenkin lykkää parannuksentekoaan, joka ei siksi lopussakaan näytä todennäköiseltä. Myös esimerkiksi Defoen Moll Flanders ja tuntemattoman tekijän Lazarillo de Tormes päättyvät kumpikin tavallaan ironisesti.

Niin ironinen teos kuin Don Quijote onkin, sen lopussa tapahtuva päähenkilön "järjen kirkastuminen romanttisista sumuista," kuten Tarkiainen sanoo (1915/1951, 390), toisin sanoen paraneminen hulluudesta ja hullujen seikkailujen katuminen, ei ironisoidu. Jos Cervantes olisi antanut epäluotettavan minäkertojan, siis Quijoten itsensä, kertoa tarinan, tilanne saattaisi olla toinen. Heterodiegeettinen kertojakin voisi ironisoida Don Quijoten kääntymystä esimerkiksi kyseenalaistamalla sen, mutta näin ei tapahdu. Yksi syy siihen on tietenkin se, minkä kertoja toisen osan lopussa mainitsee teoksensa tarkoitukseksi: "saada ihmiset inhoamaan ritariromaanien keksittyjä ja mahdottomia historioita" (Cervantes 1966: 598.) Hidalgo tulee lopussa järkiinsä, eikä tästä asiasta tehdä romaanissa pilaa. On tietenkin mahdollista nähdä koko asetelma, 
hulluudesta paraneminen kuoleman edessä, syvästi ironisena. Psykologiselta kannalta voimme pohtia asiaa mielen jakautumisen kannalta: missä määrin Quijote on koko ajan tiennyt kuvittelevansa maailmansa tahallaan kiehtovammaksi kuin se onkaan? Onko hullun, narrin ja veijarin välillä sittenkään niin suurta eroa?

Miten sitten on seitsemän veljeksen parannuksen laita? Ironisoiko kertoja heidän parannustaan? Ei, sillä, kuten Kinnunen on osoittanut, ironia Seitsemässä veljeksessä ei yleensäkään ole peräisin kertojasta vaan tilanteista. Aarne Kinnunen sanoo sitä "kohtalon ironiaksi", jossa tilanteet ironisoivat toisensa eräänlaisen peripetian kuvion mukaan. (Kinnunen 1973/1987: 74, 90-94.) Tyypillistä on, että hyvät aikeet muuttuvat suorastaan vastakohdakseen. Esimerkiksi Taula-Matin herooisen kertomuksen innoittama metsästysmatka ironisoituu, kun Viertolan karjaa ahdistelleen karhun lisäksi veljekset Hiidenkivelle ahdistettuina joutuvatkin ampumaan kaikki Viertolan 40 härkää. Tilanteiden ja henkilöiden luomaa ironiaa ja huumoria on myös romaanin viimeisissä, 13. ja 14. luvussa, vaikka aivan viimeisessä luvussa se on vaimeampaa. Kuten Lyytikäinen on osoittanut, lukkarin romaanin tapahtumia kiteyttävä puhe 13. luvussa on vakava-naurullinen, "toisinto Laurin pilasaarnasta" (Lyytikäinen 2004, 251253). Veljesten parannus ei sinänsä ironisoidu, ainoastaan lukkarin juhlallisen totinen, raamatullinen puheenparsi ja tapa ymmärtää parannuksen tarkoitus ironisoituvat.

Huumorin vaimeneminen viimeisessä luvussa johtuu vain siitä, että kertoja on taas yksin äänessä. Voimme kuvitella, että jos veljekset saisivat äänensä kuuluville, koominen sanailu kajahtelisi edelleenkin. Romaanin lopussa siis nauru vaimenee, mutta veljesten elämäntilanteissa voi nähdä ironiaa. Veljesten elämä asettuu uomiinsa, ja useimmat heistä vakiintuvat, mutta joskus tulee juopoteltua ja "rähmästeltyä", mistä vaimot saavat syyn nalkuttaa. Kinnusen analysoima "kohtalon ironia" on vahvaa loppuluvussakin. Ironista, ja samalla traagista, on hurskaan Simeonin alkoholismi ja se, että joukon narrista, Eerosta, tulee veljessarjan vakavahenkisin ja isänmaallisin hahmo, jonka melankolinen vaimo laulelee kuolemasta lapsensa kehdon ääressä. Veljesten parannus ei ole ihmeenkaltainen, eikä heistä kuoriudu kertaheitolla täydellisiä, vaan viimeisessä luvussa kuvailtu elämä on tavallista inhimillistä elämää.

\section{Viitteet}

\footnotetext{
${ }^{1}$ August Ahlqvist-Oksasen arvostelu Seitsemästä veljeksestä ilmestyi Finlands Allmänna Tidningen -lehdessä 1870, numerot 115-121. Aiheesta kirjoittaa esim. Kohtamäki 1956. ${ }^{2}$ Lyytikäinen $(2004,30)$ huomauttaa orpouden olevan pikareskiromaanien päähenkilöiden tärkeä tunnusmerkki, mutta ei pohdi Seitsemän veljeksen suhdetta pikareskin lajiin yhtään sen enempää.

${ }^{3}$ Esimerkkinä voi mainita vanhimman täysin säilyneen roomalaisen romaanin, Apuleiuksen Kultaisen aasin ja Sinuhen tarinan muinaisesta Egyptistä (n. 2000 eaa.; ks. Moore 2010, 39-41).

${ }^{4}$ Ks. Salin 2008.
} 
${ }^{5}$ Wicks myötäilee tässä kuten muuallakin Guillénin ajatuksia ja ihmettelee, että monet ansioituneetkin tutkijat, varsinkin englantilaiset, ovat erehtyneet pitämään Don Quijotea pikareskina: "erehdys, jota hispanistit eivät koskaan tekisi” (Wicks 1989, 14). Pikareski on kuitenkin levinnyt niin laajalle Espanjan ulkopuolelle, että lajin määritteleminen ei voi enää olla hispanistien yksinoikeus.

${ }^{6}$ Don Quijoten kertoja on heterodiegeettinen (ei osallistu tarinan tapahtumiin) vaikka puhuukin minämuodossa.

${ }^{7}$ Vanhemmissa kirjallisuushistorioissa Don Quijotea ei yleensä pidetä pikareskina, mutta uudemmissa sekä useimmissa internetistä löytämissäni artikkeleissa (esim. Wikipedia) se on tavallista. Pekka Vartiainen sanoo kirjallisuushistoriassaan, että Don Quijotessa on kysymys "eräästä pikareskiromaanin variaatiosta" (Vartiainen 2009, 228).

${ }^{8}$ Seitsemän veljeksen monilajisuudesta ks. Lyytikäinen 2004, 180-201.

${ }^{9}$ Lajista tulee Bahtinin mukaan oma kielensä, jonka kirjailija hallitsee tiedostamatta kaikkia sen sääntöjä: ”Jotta tämän kielen voisi hallita, ts. jotta voisi kirjallisuudessa kiinnittyä karnevaalin genretraditioon, kirjailijan ei tarvitse tuntea tuon tradition kaikkia renkaita tai haarautumia. Genrellä on oma sisäinen logiikkansa, jonka voi tietyssä mielessä ymmärtää ja omaksua luovasti muutamien genre-esimerkkien, jopa katkelmien perusteella.” (Bahtin 1991, 228.)

\section{Lähteet}

BaHtin, MiHail i 979: Kirjallisuuden ja estetiikan ongelmia. Suom. Kerttu KyhäläJuntunen ja Veikko Airola. Moskova: Progress.

BaHtin, mihail i99 I: Dostojevskin poetiikan ongelmia. Suom. Paula Nieminen ja Tapani Laine. Helsinki: Orient Express.

BIEDERMANn, HANS I993: Suuri symbolikirja. Suomentanut ja toimittanut Pentti Lempiäinen. Helsinki: WSOY.

Cervantes saAvedra, Miguel de i966: Mielevä hidalgo Don Quijote manchalainen. Jälkimmäinen osa. Suom. J. A. Hollo. Helsinki: WSOY.

Dunn, Peter N. I993: Spanish Picaresque Fiction. A New Literary History. Ithaca and London: Cornell University Press.

FOWLER, ALASTAIR I982: Kinds of Literature: an introduction to the theory of genres and modes. Oxford: Clarendon.

GUillén, Claudio I97I: Literature as System. Essays Toward the Theory of Literary History. Princeton, N. J.: Princeton University Press.

JUSSILA, RAIMO \& LÄNSIMÄKI, MAIJA I 994: Se siitä. Suomen kielen seksisanakirja. Helsinki: WSOY.

KASAla, KALEVI I99I: Ortodoksisuuden mitä, miksi, miten - kirkkotiedon käsikirja. Ortodoksisten Nuorten Liitto.

KINNUNEN, AARNE I973/I987: Tuli, aurinko ja seitsemän veljestä. Tutkimus Aleksis Kiven romaanista. Tietolipas 106. Helsinki: SKS.

KINNUNEN, AARNE 2002: Seitsemän veljestä ja lukemisen juonet. Helsinki: WSOY. 
KIVI, ALEKSIS I984: Teokset. II nide. Helsinki: SKS.

контамёкI, ILMARI I956: Ankara puutarhuri. August Ablqvist suomen kielen ja kirjallisuuden arvostelijana. Helsinki: SKS.

Koskenniemi, v.A. 1934: Aleksis Kivi. Helsinki: WSOY.

KupIaInen, unto I939: Huumori suomalaisessa kirjallisuudessa. I osa: Aleksis Kivi ja 1880-luvun realistit. Helsinki: SKS.

KUUSI, MATTI I984: Seitsemän veljeksen synty. Teoksessa Aleksis Kiven maailmasta.

Esseitä ja tutkielmia. Toim. Markku Envall. Kirjallisuudentutkijain Seuran vuosikirja 37. Helsinki: SKS.

LYYTIKÄINEN, PIRJO 2004: Vimman villityt pojat. Aleksis Kiven Seitsemän veljeksen laji. Helsinki: SKS.

MATSON, ALEX I947/I969: Romaanitaide. Kolmas painos. Helsinki: Tammi.

moore, steven 20io: The Novel. An Alternative History. London, New York: Continuum.

MÖRne, ARVID I9II: Alexis Kivi och hans roman "Seitsemän veljestä". Helsinki: Aktiebolaget Ateneum.

SALIN, SARI 2008: Narri kertojana. Kultaisesta aasista suomalaiseen postmodernismiin. Helsinki: SKS.

TARKIAINEN, v. I91 5/I95 I: Aleksis Kivi. Elämä ja teokset. Helsinki: WSOY.

VARTIAINEN, PEKKA 2009: Länsimaisen kirjallisuuden historia. Helsinki: BTJ Kustannus. WICKs, UlRICH 1989: Picaresque Narrative, Picaresque Fictions. A Theory and Research Guide. Westport, Connecticut: Greenwood Press. 